\title{
Correction to: Infrapatellar fat pad-derived mesenchymal stem cell-based spheroids enhance their therapeutic efficacy to reverse synovitis and fat pad fibrosis
}

Dimitrios Kouroupis ${ }^{1,2}$, Melissa A. Willman ${ }^{2}$, Thomas M. Best ${ }^{1}$, Lee D. Kaplan ${ }^{1}$ and Diego Correa ${ }^{1,2^{*}}$

\section{Correction to: Stem Cell Res Ther 12, 44 (2021) \\ https://doi.org/10.1186/s13287-020-02107-6}

The original article [1] contained typesetting errors in Figs. 2 and 4, mistakenly introduced by the production team that managed this article.

These errors have both since been corrected.

Published online: 11 May 2021

\section{Reference}

1. Kouroupis D, Willman MA, Best TM, Kaplan LD, Correa D. Infrapatellar fat pad-derived mesenchymal stem cell-based spheroids enhance their therapeutic efficacy to reverse synovitis and fat pad fibrosis. Stem Cell Res Ther. 2021;12(1):44. https://doi.org/10.1186/s13287-020-02107-6.

\footnotetext{
The original article can be found online at https://doi.org/10.1186/s13287020-02107-6.

* Correspondence: dxc821@med.miami.edu

'Department of Orthopedics, UHealth Sports Medicine Institute, Miller School of Medicine, University of Miami, 1450 NW 10th Ave (3014), Miami, FL 33136, USA

${ }^{2}$ Diabetes Research Institute \& Cell Transplantation Center, Miller School of Medicine, University of Miami, 1450 NW 10th Ave (3014), Miami, FL 33136, USA
}

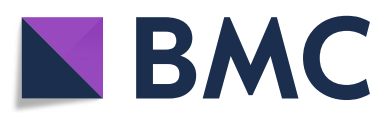

(- The Author(s). 2021 Open Access This article is licensed under a Creative Commons Attribution 4.0 International License, which permits use, sharing, adaptation, distribution and reproduction in any medium or format, as long as you give appropriate credit to the original author(s) and the source, provide a link to the Creative Commons licence, and indicate if changes were made. The images or other third party material in this article are included in the article's Creative Commons licence, unless indicated otherwise in a credit line to the material. If material is not included in the article's Creative Commons licence and your intended use is not permitted by statutory regulation or exceeds the permitted use, you will need to obtain permission directly from the copyright holder. To view a copy of this licence, visit http://creativecommons.org/licenses/by/4.0/. The Creative Commons Public Domain Dedication waiver (http://creativecommons.org/publicdomain/zero/1.0/) applies to the data made available in this article, unless otherwise stated in a credit line to the data. 